\title{
Das amarras do poder às entrelinhas do discurso: a pedagogia ambígua da favela em Capão pecado, de Ferréz
}

\author{
Juan Filipe Stacul*
}

\begin{abstract}
Resumo
Pretende-se, no presente trabalho, investigar como o narrador de Capão pecado propõe um contraponto ao código de moral da marginalidade, assumindo um tom pedagógico ambíguo que, ao mesmo tempo, critica o "sistema" e valoriza as regras de moralidade por este apregoadas. Para tal análise, pretende-se relacionar a instância narrativa da obra em questão com os pressupostos teóricos de Michel Foucault sobre a dissolução das relações de poder, representada pela figura do panóptico. Verifica-se, com isso, que os valores morais da sociedade tradicional burguesa se dissolvem nas mais diversas estruturas, diluindo, nesse processo, algumas fronteiras entre centro e margem para se estabelecer como norma até mesmo onde são questionados e subvertidos.
\end{abstract}

Palavras-chave: Relações de poder. Literatura marginal. Ferréz. Capão pecado.

Ouvi centenas de depoimentos de pessoas que tiveram o Capão pecado como sua primeira leitura, mas o livro foi escrito principalmente para que

a história desse povo, dessa época não fosse esquecida, eu queria eternizar essas pessoas, deixá-las vivas, pelo menos no livro.

(FERRÉZ, 2013).

\section{Introdução}

A epígrafe em questão, extraída da nota escrita por Ferréz para apresentar a edição recente de Capão pecado (2013), é bastante representativa do debate que pretendemos levantar no presente trabalho: um estudo acerca do tom pedagógico da narrativa de Ferréz e seus possíveis desdobramentos, que transpassam as linhas do romance de forma ambígua, contraditória, colocando em xeque a possibilidade

* Universidade Federal de Viçosa (UFV). Doutor em Literaturas de Língua Portuguesa pela Pontifícia Universidade Católica de Minas Gerais (PUC Minas). Bolsista PNPD/CAPES. 
de delimitação ideológica da instância narrativa, ante a intromissão de vozes sociais que a perpassam a todo o momento. Nesse sentido, pretendemos verificar como o narrador de Capão pecado propõe um contraponto ao código de moral da marginalidade, assumindo um tom pedagógico ambíguo que, ao mesmo tempo, critica o "sistema" e valoriza as regras de moralidade por este pregoadas. Para tal análise, relacionaremos a instância narrativa da obra em questão com os pressupostos teóricos de Michel Foucault sobre a dissolução das relações de poder, representada, de maneira emblemática, em Vigiar e punir (2009), pela figura do panóptico. Verificamos, com isso, que os valores morais ditos da sociedade tradicional burguesa se dissolvem nas mais diversas estruturas, diluindo, nesse processo, algumas fronteiras entre centro e margem para se estabelecer como norma até mesmo onde são questionados e subvertidos.

É importante mencionar que a constituição de um tom pedagógico na voz narrativa se constrói, sobretudo, por meio de recursos textuais e estilísticos que se apresentam a partir da inserção do cotidiano da favela ${ }^{1}$ e da proposta de identificação e/ou catarse do leitor diante do conteúdo linguístico e temático presente no romance. Nesse sentido, pretendemos, após a discussão teórica supracitada, identificar quais elementos textuais são utilizados pelo narrador nesse processo e de que modo se evidenciam uma defesa e, paradoxalmente, ao mesmo tempo, a traição de determinados valores normativos. Torna-se indispensável, nesse ínterim, verificar quais questões são defendidas e quais são criticadas pela instância pedagógica e como isso ocorre; objetivo este que pretendemos percorrer a partir de uma análise do narrador de Capão pecado que, aparentemente, apesar de comungar do universo cultural que esboça em seus relatos, se distancia, de forma abrupta, de determinadas práticas sociais, lançando um olhar avaliativo, questionador e, inclusive, punitivo aos seus pares.

A seguir, portanto, debateremos as questões aqui levantadas de forma mais abrangente, na tentativa de uma conclusão que aponte para os possíveis desdobramentos críticos do romance de Ferréz. Para tanto, dividiremos nossa análise em quatro partes: em um primeiro tópico, o qual denominamos "Sem inspiração para cartão postal”, faremos um breve percurso pela trajetória sobre

1 Ressalta-se que conceitos como "favela", "moral da favela", etc. são utilizados em nosso trabalho como referência a uma "favela literária" e a valores morais e ideológicos comumente representados em obras literárias que se propõem a reconstruir artisticamente o cotidiano em espaços marginalizados. Não pretendemos, nesse sentido, tecer qualquer crítica sociológica e/ou antropológica - pois compreendemos a "favela literária" como uma interpretação particular de determinado espaço e não como uma fotografia linear da realidade contemporânea. 
o autor e sua obra. No segundo tópico, chamado "Nas armadilhas do poder", apresentaremos a teorização de Michel Foucault sobre o conceito de poder, que servirá de sustentáculo para nossa leitura crítica. Nos tópicos seguintes, "Uma pedagogia ambígua da favela" e "No entre-lugar dos sistemas", discorreremos sobre a pedagogia apregoada pelo narrador de Capão pecado e a ambiguidade que escapa pelas entrelinhas de seu posicionamento ideológico.

\section{2 "Sem inspiração para cartão postal”}

O título desta seção, referência à legenda de uma das imagens da primeira edição de Capão pecado (2000) e ao trabalho da pesquisadora Luciana Mendes Velloso, Capão pecado: sem inspiração para cartão postal (2007), remete à favela de Capão Redondo, Zona Sul de São Paulo, em que nasceu Reginaldo Ferreira da Silva, O Ferréz - e que, apesar do que se sugere na legenda em questão, serviu de "cartão postal" para a ambientação de seu romance.

Nome bastante representativo para a gênese e a divulgação de uma nova Literatura Marginal ${ }^{2}$, Ferréz ficou conhecido ao trazer para o cenário brasileiro contemporâneo uma literatura sobre a favela, produzida por um morador deste espaço e destinada a seus pares. A obra de Ferréz, no entanto, ultrapassou os limites da marginalidade para se inserir em universos outrora inesperados, tanto no quesito da crítica acadêmica quanto de público leitor. Conforme pode ser observado no texto biográfico Ferréz: o rapper da Literatura (2012), de Maria Aparecida Costa dos Santos, a trajetória literária do escritor perpassa um movimento que vai desde a escrita em tempo livre, quando Ferréz trabalhava como balconista, auxiliar de serviços gerais e arquivista, até sua recente notoriedade, quando começou a se dedicar por completo à literatura.

Além de Capão pecado, sua obra prima, Ferréz é autor de Fortaleza da desilusão (1997), Manual prático do ódio (2003), Amanhecer para Esmeralda (2005), Ninguém é inocente em São Paulo (2006), Cronista de um tempo ruim (2009) e Deus foi almoçar (2012). Em todas as obras, vislumbramos temáticas

2 Cientes das várias atribuições do termo Literatura Marginal na crítica contemporânea, assim como de sua elasticidade conceitual, designamos a literatura de Ferréz de "nova" Literatura Marginal em contraste às produções do Movimento Mimeógrafo (1970) e da Literatura Marginal das décadas seguintes. Especificamente no nosso trabalho, o termo Literatura Marginal designa o movimento estético-literário divulgado pela revista Caros Amigos e produzido por escritores dos subúrbios e favelas, com temática centrada nesses ambientes. 
recorrentes, como a crítica à alienação do sistema capitalista e da grande mídia e o lugar ocupado pelos indivíduos pobres, assim como outros questionamentos de ordem social e política. Ferréz atua ativamente, ainda, como líder de movimentos sociais voltados para a formação de jovens na favela e para a valorização da cultura periférica - dentre estes, a grife 1DaSul. É extremamente engajado com os movimentos de expressão de grupos marginalizados e porta-voz da Literatura Marginal produzida por esses grupos, em um panorama internacional.

Sobre a obra de Ferréz que utilizaremos como corpus para o nosso estudo, ressalta-se que Capão pecado é um relato verossímil da realidade vivenciada pelos moradores da periferia de Capão Redondo. Com agilidade e sem floreios, são retratados momentos cotidianos da realidade local, captados pelo olhar arguto de Ferréz, que ainda é residente da favela e que, segundo o próprio autor, experenciou muito do que se encontra retratado em sua obra. O caráter "realista" do romance se dá, desde o início, pela escolha de Ferréz em adotar personagens reais na sua narrativa, ou seja, trazer para o universo literário histórias realmente vividas pelos sujeitos que protagonizam o romance e cujos nomes foram mantidos conforme o original.

O protagonista de Capão pecado é Rael, um jovem morador de Capão Redondo, trabalhador e honesto, que vê seu mundo entrar em conflito quando, abruptamente, apaixona-se pela namorada de seu melhor amigo. Paralelamente à história de Rael, recortadas e fragmentadas são tecidas as histórias dos moradores de Capão Redondo, num entremear de crônicas que se aproximam por meio de algumas linhas nodais, tais como o intenso processo de repressão do sistema capitalista, a crítica a determinados valores morais e a constante presença da violência e da miséria.

Nesse contexto, emerge uma série de relações sociais que são caras às discussões que pretendemos realizar no presente trabalho. Estas traçam um perfil moral e ideológico que suscita uma série de debates sobre a solidificação de determinadas estruturas culturais, muito bem evidenciadas no romance em questão, e que dialogam diretamente com uma noção de poder que pretendemos apresentar a seguir. Para tanto, selecionamos um arcabouço teórico embasado no conceito de poder de Michel Foucault (2009), por acreditarmos ser de essencial importância para a percepção das estruturas que se edificam no romance em questão. 


\section{Nas armadilhas do poder}

Michel Foucault, no capítulo "O Panoptismo", do canônico livro Vigiar e punir (2009), apresenta-nos uma imagem essencial à compreensão das estruturas de poder e de seus desdobramentos nas práticas cotidianas: a de uma cidade em quarentena diante do perigo iminente de uma contaminação epidemiológica. Em sua discussão, Foucault descreve minuciosamente as práticas cotidianas de isolamento dos sujeitos pestilentos e de controle social dos locais afetados pela doença. Leva-nos, com isso, a verificar como as relações de exclusão e de controle transcendem a assimétrica relação entre o governo (ou o órgão responsável pelo controle da peste) e a população, para se inserir no âmago das relações entre amigos, parentes e conhecidos. Um vigia o outro, um controla o outro e um aponta para o outro, caso localize indícios de doença.

A imagem da cidade sitiada é relacionada, por Foucault, ao modelo arquitetônico do panóptico, de Jeremy Betham, segundo o qual uma torre de vigilância, no centro de uma prisão circular, desempenha uma vigilância aparentemente unilateral, mas que, ao cegar os detentos sobre o fato de estarem ou não sendo vigiados, acaba por promover uma dissolução do controle entre os próprios seres vigiados, fazendo com que observem a si mesmos e sejam atores de mecanismos de vigilância e de julgamento de seus pares. A partir de tais exemplos, Foucault conclui:

Quem está submetido a um campo de visibilidade, e sabe disso, retoma por sua conta as limitações do poder; fá-las funcionar espontaneamente sobre si mesmo; inscreve em si a relação de poder a qual ele desempenha simultaneamente os dois papéis; torna-se o princípio de sua própria sujeição. (FOUCAULT, 2009, p. 192).

A noção de poder, portanto, para Foucault, não pode ser compreendida a partir de uma noção binária e assimétrica que coloca o dominador de um lado e o dominado do outro, mas de uma série de relações que se instauram na fluidez e na não linearidade. Os sujeitos, quando engendrados pelas estruturas sociais do mundo que os cercam, tornam-se executores de mecanismos de dominação, ao mesmo tempo em que estão constantemente sendo observados por seus pares e, consequentemente, (re)construindo relações de poder.

A partir de tais considerações, podemos vislumbrar que, conforme nos aponta Foucault, as relações de poder se constroem em rede, diluídas nas práticas 
cotidianas, sendo reestruturadas de diversas formas nos mais diversos contextos. Do mesmo modo, os discursos e as ideologias estão sempre perpassados por uma série de variáveis que, apesar da necessidade marcada de definição em determinadas categorias, expõe uma série de ambiguidades. A esse respeito, Foucault afirma:

$\mathrm{O}$ poder funciona. $\mathrm{O}$ poder se exerce em rede e, nessa rede, não só os indivíduos circulam, mas estão sempre em posição de ser submetido a esse poder e também de exercê-lo. Jamais eles são o alvo inerte ou consentidor do poder, são sempre seus intermediários. Em outras palavras, o poder transita pelos indivíduos, não se aplica a eles. (FOUCAULT, 2002, p. 35, grifo nosso.)

Tal assertiva nos direciona a um pensamento segundo o qual é impossível que determinada relação de poder se construa unilateralmente, ou que os discursivos produzidos dentro desse mesmo contexto possam ser, de alguma forma, unívocos, não contaminados por pensamentos que lhe são externos ou, até mesmo, ideologicamente contrários. Acreditamos, portanto, que dentro dessas relações de poder se instauram ambiguidades e até mesmo paradoxos que, antes de colocarem em prova a solidez das relações que ali se constituem, apontam para a própria edificação multifacetada das culturas, das ideologias, das sociedades e dos sujeitos. Tudo estaria, assim, tecido em um grande mosaico, uma multiforme colcha de retalhos.

A noção de poder apresentada por Foucault nos é cara para uma percepção do processo de assimilação e dissolução que ocorre no romance de Ferréz. O narrador de Capão pecado, ao se compreender como porta-voz de uma classe social, constitui-se como uma ferramenta de (re)construção de relações de poder. No tom pedagógico que assume, a voz narrativa levanta-se contra o que chama de "sistema", aqui compreendido como o microuniverso da classe média e dos afortunados, dos detentores do capital e de um estilo de vida, de algum modo, bem distante da realidade das favelas. Nesse contexto, o narrador coloca-nos diante de constantes exemplos em que o mais rico humilha o mais pobre (FERRÉZ, 2013, p. 91) ou em que grandes corporações abusam da inocência do trabalhador ingênuo e sem escolaridade. (FERRÉZ, 2013, p. 19-20).

O narrador de Ferréz se constrói, portanto, como uma voz professoral que julga o comportamento negativo daqueles que tudo possuem, mas que "não dão valor pra nada" (FERRÉZ, 2013, p. 178). Evidencia as máculas da sociedade capitalista e os valores negativos engendrados por um sistema que põe sempre a matéria em 
posição superior ao ser. Não são escassos, nesse sentido, os momentos em que a narrativa lança um olhar questionador, crítico e julgador.

O que podemos verificar, no entanto, se aprofundarmos nossa leitura, é que as relações de poder colocadas em xeque pelo narrador de Ferréz se mostram mais complexas do que podem parecer em um primeiro momento. $\mathrm{O}$ narrador mergulha em um discurso ambíguo, multifacetado, e incorpora elementos que são constituintes e até mesmo basilares do 'sistema' que tão veementemente critica, incorporando-os ao que poderíamos denominar de pedagogia da favela, subvertendo sua própria 'cartilha' e julgando o comportamento de seus pares sobre o crivo de um pensamento que outrora tão fortemente criticara.

Nos próximos tópicos, a partir de uma análise de trechos de Capão pecado, pretendemos apresentar o que aqui chamamos de pedagogia da favela para, então, mostrarmos como se promove esse processo de profusão que redimensiona todo um conceito moral, convertendo-a em uma pedagogia ambígua - o que, de maneira alguma, como veremos, a invalida em sua funcionalidade básica de se tornar veículo de expressão e de constituição de uma arte - e de uma literatura - da favela e para a favela.

\section{Uma pedagogia ambígua da favela}

Para que possamos traçar um esboço eficaz do que pretendemos denominar "pedagogia da favela", é necessário, primeiramente, que tenhamos em mente o que compreendemos como pedagogia e o que pretendemos caracterizar como "da favela". Trata-se de tarefa árdua, repleta de percalços conceituais e ideológicos, mas não pretendemos cumpri-la com a pretensão de estabelecermos um conceito totalizante das relações que se constituem na favela, enquanto espaço literário, ou mesmo no que se convenciona, atualmente, denominar de literatura marginal.

É importante ressaltar, inicialmente, que a pedagogia à qual nos referimos está mais para uma dicção pedagógica, ou, se assim preferirmos, para uma forma de expressão escrita que demonstra uma pretensão didática por parte da instância narrativa, configurando a escrita romanesca com que se pretende defender uma tese, corroborar um ponto de vista e ensinar algo a determinado público leitor. Nesse sentido, verificamos que, com bastante frequência, o texto de Ferréz assume forte teor argumentativo presente na voz narrativa. Os fatos narrados, muitas vezes, tornam-se ilustrações para defesa ou corroboração de uma tese - o 
que a colocaria, portanto, segundo a noção que ora propomos, na posição de um romance pedagógico. Textualmente, podemos verificar que a argumentatividade pedagógica seria marca constituinte de Capão pecado a partir de três movimentos básicos:

1) a linguagem direta e econômica, que se aproxima bastante da objetividade de textos pedagógicos, com ilustrações constantes que direcionam o leitor para determinado ponto de vista;

2) a inserção de textos de personalidades, possivelmente conhecidas pelo leitor, entre os capítulos, que servem como argumento de autoridade para reforçar as ideias do narrador;

3) a seleção lexical constituída, basicamente, pela norma coloquial da língua e por expressões de uso cotidiano no universo ficcional da favela.

Assim, bastaria que retomássemos a nota inicial do livro, transcrita no início do presente trabalho, para comprovarmos que o estabelecimento de uma literatura pedagógica estaria inserido desde o início na proposta estética e artística de Ferréz. Nesse sentido, o próprio autor é quem nos esclarece como o romance em questão poderia ser utilizado como uma ferramenta de conscientização e de ensinamento dos moradores da favela.

A partir de tais considerações, somos conduzidos a refletir sobre o segundo elemento constituinte da terminologia proposta, ou seja, o que seria, afinal, uma pedagogia "da favela". Mais do que evidenciar um público leitor específico, a favela é aqui compreendida como um espaço literário constituinte de uma cultura própria e relativamente singular na sua relação com as estruturas normativas tradicionais. Nesse sentido, é bastante representativa a imagem suscitada por Paulo Lins (2014), autor de Cidade de Deus (2012), segundo a qual

a incitação à violência é uma maneira de defesa, pois a polícia vem matando, inclusive inocentes. A polícia brasileira é uma das que mais mata no mundo. Essa violência (das músicas) é a violência da própria sociedade brasileira, que é violenta e racista. Quer que você seja pobre, discriminado, mas ao mesmo tempo quer que você seja calmo e honesto. Não dá! Mais uma vez: se o capitalismo tivesse dado certo, sairíamos na rua sem ter arrastão. Outro ponto é que a violência governamental e social mata muito mais. $\mathrm{O}$ quanto os empresários e o governo matam de fome, ou o quanto a escola mata ensinando mal. O poder mata muito mais. (LINS, 2014). 
$\mathrm{Na}$ proposta de Paulo Lins podemos visualizar claramente a singularidade de uma pedagogia da favela, enquanto manifestação artística e cultural. No pensamento do autor, as relações sociais e culturais deste espaço se constituiriam a partir de um embate com determinadas estruturas da sociedade capitalista, especificamente, em oposição direta aos valores apregoados por uma parcela detentora do capital, alicerçada em valores tradicionais de propriedade, religião e ordem - centralizada, sobretudo, na figura do militar.

A partir de tais considerações, verificamos que a pedagogia da favela, enquanto representação ficcional de uma moralidade própria, seria aquela alicerçada, idealisticamente, na seguinte estrutura de valores ideológicos, em oposição ao centro do sistema capitalista dominante:

\begin{tabular}{|c|c|c|}
\hline & Favela & Sistema \\
\hline Herói & $\begin{array}{c}\text { O marginal } \\
\text { Subverte as estruturas } \\
\text { dominantes, protegendo os que } \\
\text { estão à margem. }\end{array}$ & $\begin{array}{c}\text { O policial } \\
\text { Insere-se nas estruturas } \\
\text { dominantes, protegendo os } \\
\text { 'homens de bem'. }\end{array}$ \\
\hline $\begin{array}{c}\text { Local de } \\
\text { Aprendizagem }\end{array}$ & $\begin{array}{c}\text { A Práxis } \\
\text { O sujeito é 'moldado' pela vida } \\
\text { sofrida na favela }\end{array}$ & $\begin{array}{l}\text { Os Aparelhos Ideológicos } \\
\text { (Religião, Escola, etc,) } \\
\text { O sujeito é 'moldado' no } \\
\text { cerne das instituições. }\end{array}$ \\
\hline Valor preponderante & $\begin{array}{c}\text { Humildade } \\
\text { Preponderância do 'ser'. }\end{array}$ & $\begin{array}{l}\text { Orgulho } \\
\text { Predominância do 'ter' } \\
\text { (capital) }\end{array}$ \\
\hline Relações sociais & $\begin{array}{c}\text { Coletividade } \\
\text { Cooperação e empatia - todos } \\
\text { pertencem a um mesmo grupo. } \\
\text { Valoriza-se o semelhante. }\end{array}$ & $\begin{array}{c}\text { Individualidade } \\
\text { Superação assimétrica da } \\
\text { coletividade. Valoriza-se } \\
\text { o que se sobressai aos } \\
\text { demais. }\end{array}$ \\
\hline $\begin{array}{c}\text { Estrutura } \\
\text { hierarquizante }\end{array}$ & $\begin{array}{l}\text { O Tráfico } \\
\text { Ascensão social se dá por meio } \\
\text { de uma gradação de funções no } \\
\text { crime organizado. }\end{array}$ & $\begin{array}{l}\text { Grandes corporações } \\
\text { Ascensão social se dá por } \\
\text { meio da cumulação de } \\
\text { altos cargos no universo } \\
\text { empresarial. }\end{array}$ \\
\hline
\end{tabular}


Obviamente, tal esquema é meramente ilustrativo da representação binária comumente atribuída ao espaço da favela na literatura e nas artes. Estabelece, sob uma visão parcial e sem pretensões totalizantes, um ponto de vista sobre os valores 'pedagógicos' da favela, de acordo com um senso comum continuamente difundido. Em Capão pecado, podemos vislumbrar momentos em que a voz narrativa assume o tom pedagógico e defende, sempre em contraponto com o pensamento do "sistema", os valores que traçamos no quadro acima. A título de exemplo, é bastante significativa a cena que segue:

Mas Rael era muito curioso, e não conseguia dormir. Algo o incomodava. Levantou-se lentamente, acendeu a luz, foi até a árvore, pegou o cartão e resolveu ler, pois quando seu pai olhava o cartão só estava fingindo entender o escrito, pois tinha vergonha de ficar dizendo que era analfabeto.

Rael leu o cartão:

"Um Feliz Natal e que seja feliz, você e toda a família, é o que nós da METALCO desejamos a todos os nossos funcionários, Amor \& Paz!"

E Rael continuou a observar o cartão, notou que atrás havia letrinhas minúsculas, e, curioso, as leu.

"Cartão comprado de associações beneficentes com efeito de abate no imposto de renda."

Era Rael sábio e entendeu aquilo.

Era Zé Pedro humilde e dormia tranquilo.

Era mais uma família comum.

Era um natal de paz. (FERRÉZ, 2013, p. 19).

Como podemos observar, neste excerto do romance fica claro que a cena narrada se insere como uma espécie de estratégia argumentativa. Nesse ínterim, corrobora a tese do narrador de que o pensamento capitalista, ao valorizar o ter em detrimento do ser, é responsável por um processo de alienação e de domesticação das massas populares. Ironicamente, o narrador questiona os valores capitalistas e o lugar do trabalhador nos meios de produção, assim como os interesses escondidos por trás da pretensa generosidade das corporações.

Do mesmo modo, em determinado momento, ao colocar Rael na frente da televisão, questionando o caráter alienante dos comerciais e da programação televisiva de modo geral (FERRÉZ, 2013, p. 23-24), o narrador aproveita para lançar uma crítica negativa à mídia, como parte desse processo de domesticação política e ideológica dos sujeitos "mais humildes" (FERRÉZ, 2013, p. 23). No trecho que segue, podemos visualizar um momento em que o narrador assume 
o teor pedagógico mais explicitamente, levantando-se contra as estruturas normativas do sistema capitalista:

E, num futuro certo e premeditado, aqueles garotinhos que ela ajudava a criar e a alimentar seriam grandes empresários como o pai, e com certeza os netos daquela simples dona Maria seriam seus empregados mal assalariados e condenados a uma vida medíocre. (FERRÉZ, 2013, p. 91.)

O sistema capitalista é vislumbrado, conforme nos sugere o trecho em questão, sob uma ótica repressiva e até mesmo determinista, enquanto mecanismo de verticalização das relações de poder. Essa crítica se estende por todo o romance, quando personagens pertencentes a uma classe social economicamente confortável são continuamente descritos em atos torpes de dominação, posse, traição e humilhação dos moradores pobres da favela. Ser detentor do capital, não apenas no romance em questão, mas sob o viés da pedagogia da favela na literatura marginal, situa-se em um local de tensão entre esferas sociais, não apenas por representar um estilo de vida baseado no individualismo e na dominação, mas por, muitas vezes, ferir um elemento caro à moral da favela: a humildade.

Nesse contexto, poderíamos vislumbrar a figura do malandro e, posteriormente, a do marginal, como um paradigma de subversão idealizado no universo da favela, ao se constituir como aquele que não apenas subverte a lógica repressiva do capital, retirando bens materiais daqueles que o ostentam sem o merecerem, mas como aquele que põe sob suspeita os valores basilares da sociedade burguesa, ao conseguir ascensão social e econômica por meios que estão além do tão valorizado trabalho árduo nas grandes corporações.

Um elemento representativo do processo a que nos referimos seria o constante tom de revolta que o narrador de Capão pecado atribui aos seus comentários pessoais quando se propõe a relatar a realidade dos trabalhadores das classes populares. A própria linguagem, ao se tornar cada vez mais violenta, desnuda uma raiva pungente, pronta para ser detonada sob a mais ínfima pressão - e que, constantemente, eclode no discurso pedagógico do narrador, imbricando-se ao pensamento das personagens, por meio do discurso indireto livre:

Rael ouviu ao fundo um maluco dizendo que trabalhou para um burguês filho da puta que tinha de tudo, tinha piscina, um jipinho 
para ele brincar com seu filho, com motor e tudo, uma puta árvore de Natal forrada de presentes; mas quando olhava para ele só via ganância e desapontamento. $\mathrm{O}$ burguês filho da puta num dava valor pra nada. (FERRÉZ, 2013, p. 178).

Se observarmos o trecho com mais atenção, no entanto, vamos perceber que ocorre uma transposição da moral da favela para reverberar uma nuance ideológica que escapa às barreiras discursivas. Há, nesse caso, uma infiltração de um discurso que seria contrário ao defendido pelo narrador e uma evidência daquilo que pretendemos denominar de ambiguidade. Ou seja, quando observamos o tom de revolta do narrador, vemos que este se dá não pelo fato da alta concentração de renda e de bens materiais nas mãos de um único indivíduo, mas pelo "não merecimento" desse sujeito. Ou seja, não há uma crítica à acumulação de capital, mas a sua valoração.

Nas próximas linhas, pretendemos discutir como essa intromissão da ideologia capitalista se insere na voz narrativa de Capão pecado, constituindo não apenas a supracitada ambiguidade de pontos de vista, mas uma pedagogia da favela multifacetada e polifônica, que em alguns aspectos se distancia do tom pedagógico de outros narradores marginais, como o de Paulo Lins, por exemplo. A partir dessa multiplicidade discursiva e ideológica, a narrativa em questão põe em xeque não apenas a impossibilidade de se vislumbrar uma pedagogia unívoca da favela na literatura marginal, mas o próprio caráter transitório das relações de poder e das reverberações nas práticas sociais cotidianas, tão bem representadas na prosa de Ferréz.

\section{No entre-lugar dos sistemas}

Advindo da obra de Silviano Santiago (2000), o conceito de entre-lugar designa aquilo que passeia entre fronteiras, sem se estabelecer em um lugar rígido ou estável. Estabelece-se, em vez disso, numa posição dialógica, ambígua, na qual se assimilam características e valores referentes a universos distintos e, muitas vezes, antagônicos. Ao se referir ao entre-lugar como caracterizador da literatura latino-americana, o autor afirma:

Entre o sacrifício e o jogo, entre a prisão e a transgressão, entre a submissão ao código e a agressão, entre a obediência e a rebelião, 
entre a assimilação e a expressão - ali, nesse lugar aparentemente vazio, seu templo e seu lugar de clandestinidade, ali, se realiza o ritual antropófago da literatura latino-americana. (SANTIAGO, 2000, p. 26).

Énesse entre-lugarenunciativoque situamos anarrativadeFerréz. Transgressora, ela traz para o cenário artístico as vozes que não queriam ser ouvidas e, ao mesmo tempo, assimila nessas vozes o discurso daqueles que a silenciaram. Esse processo, no entanto, não deve ser visto como algo negativo, mas como uma das armas mais afiadas de Capão pecado: ao transitar entre espaços e incorporar diferentes perspectivas, o romance se torna multidimensional, denunciando que o poder da norma e dos discursos opressores se instaura nos lugares mais inimagináveis, amarrando os sujeitos em armadilhas de difícil escape. A pedagogia ambígua da favela, nesse contexto, reverbera uma posição estética e política marcada pela nuance, pelos interstícios e, consequentemente, pelo seu antropofagismo. Nas palavras de Santiago, "a maior contribuição da América Latina para a cultura ocidental vem da destruição sistêmica dos conceitos de unidade e de pureza: estes dois conceitos perdem o contorno exato de seu significado, perdem seu peso esmagador, seu sinal de superioridade" (SANTIAGO, 2000, p. 16).

$\mathrm{O}$ primeiro elemento que podemos situar, enquanto representativo de uma multifacetada construção ideológica presente no romance de Ferréz, é o modo como o narrador lida com a inserção das personagens no mercado de trabalho. De um lado, conforme observado anteriormente, a voz narrativa lança julgamentos pesados à estrutura assimétrica das grandes corporações, enquanto, do outro, deixa transparecer, por meio da intromissão no pensamento das personagens, uma vontade e, até mesmo, necessidade de ascensão social dentro do universo capitalista.

O pensamento visualizado, nesse caso, é ambíguo ao expor um olhar de ódio lançado sobre o burguês, o playboy, já que esse olhar reverbera, mais do que uma crítica ao sistema capitalista, um antagonismo, no qual ao mesmo tempo que o sujeito está à margem, este deseja, de certa forma, pertencer ao cerne daquele sistema que o marginalizara - o lugar do dominador. A título de exemplo, destacamos o trecho a seguir:

Rael se aproximou e Halim nem o cumprimentou, só entregou o dinheiro e disse que o serviço de sua mãe estava the custando muito dinheiro. Rael não respondeu nada, só guardou o dinheiro no bolso, 
disse obrigado e se retirou. Mas Halim notou algo em seu rosto, algo estranho, talvez por um momento Halim tenha visto nos olhos daquele simples menino periférico um sentimento de ódio puro e tenha sentido por algum momento que um dia o jogo iria virar. (FERRÉZ, 2013, p. 26).

Observa-se, nesse caso, que entremeado ao ódio do personagem pelo patrão "pão-duro", está o desejo de inversão da hierarquia, de "virar o jogo". Assim, como visualizamos no tópico anterior, a crítica do narrador ao sistema é, na verdade, uma crítica ao lugar que o pobre e o favelado ocupam nesse sistema, mas não necessariamente uma crítica aos valores de aquisição de capital e ascensão social que modelam e alicerçam esse sistema. Nesse sentido, tanto a voz narrativa quanto as ações das personagens convergem para uma valorização da ascensão social e para a ocupação de lugares restritos à classe burguesa por parte das personagens da favela.

Ao contrário de outros textos representativos da denominada literatura marginal contemporânea, assim como de obras fílmicas recentes que tratam do cotidiano nas grandes favelas brasileiras, verificamos que em Capão pecado há certa valorização do trabalho nas grandes corporações capitalistas e não a inserção das personagens no universo do crime e do tráfico. Nesse sentido, os heróis retratados são os trabalhadores braçais, os operários, etc. A figura do malandro e a do marginal deixam de ocupar o lugar central, de protagonista, para colocarem-se à margem, como pano de fundo da narrativa. Obviamente, há uma representação da criminalidade que transborda em cada linha do romance, mas o crime, o tráfico e a bandidagem são, no romance de Ferréz, constituintes estéticos do ambiente e da narrativa, mas não estruturadores do eixo nuclear do romance - pelo menos não com a intensidade e o grau de importância que ocorre em romances como Cidade de Deus, por exemplo.

A respeito do mosaico ideológico que constitui a narrativa em questão, não poderíamos deixar de mencionar a forma como o narrador lida com os conceitos de moral referentes ao corpo, à sexualidade e à estrutura familiar. Sabe-se, se retomarmos a obra de filósofos, como Michel Foucault (1988), que o controle dos corpos representa um mecanismo central de estruturação de determinadas relações de poder. Nesse sentido, o corpo abjeto (KRISTEVA, 1986) é vislumbrado sempre sob a ótica da marginalidade e do não pertencimento ao eixo nuclear que estaria situado, essencialmente, no leito familiar burguês (WOLFF, 1990). 
Seria de se esperar, sob essa ótica, que, por representar estruturas sociais à margem da ideologia burguesa, a narrativa de Capão pecado subvertesse os valores moralizantes que são a base desse sistema, tais como o casamento e a consequente constituição da família tradicional. O que ocorre, no entanto, é justamente o contrário: o narrador de Ferréz é dotado de uma forte moral cristã, tradicional, quase reacionária, que muitas vezes ocupa a torre do panóptico e julga os pecados cometidos pelos moradores da favela. Como em Quarto de despejo, de Carolina Maria de Jesus (1966), vislumbramos uma relação antitética do narrador para com a favela: ao mesmo tempo em que se aproxima da linguagem e da cultura deste espaço, tenta se distanciar moral e eticamente de tal contexto, julgando o comportamento de seus pares sob a ótica daquele que seria, em linhas gerais, o sistema opressor.

Meninas que engravidam antes da idade, filhos que não se preocupam com os pais, maridos alcoólatras, usuários de drogas: todos são colocados no patamar da abjeção e julgados pela lente da moral cristã, no entanto sob a perspectiva de um narrador que também pertence a essa margem e que deveria, na perspectiva do senso comum, defendê-los em vez de julgá-los. A seguir, a título de exemplo, podemos visualizar uma cena em que o olhar crítico do narrador se volta contra as adolescentes que engravidam 'antes da hora':

Domingo ensolarado, Rael acordou tarde. O dia estava em seu ápice, a feira já estava montada, era só abrir a janela e ver as mulheres passando. Pena que a maioria que geralmente fazia suas compras semanais já trazia suas crias. Um incidente comum, infelizmente, para a maioria das garotas entre 12 e 18 anos. Pronunciou ao levantar da cama:

Filho aqui já virou moda, criar os pequenos inocentes é que é foda. (FERRÉZ, 2013, p. 154).

O mesmo tom é observado, também, quando são criticados os filhos que desrespeitam os pais e que, com isso, colocam em crise a nuclearidade da instituição familiar (cerne das relações de poder e dos mecanismos de controle sobre os corpos e práticas):

A casa era de todo humilde, mas não se sentiam infelizes, a não ser pelo fato de seus dois filhos, Will e Dida, nunca estarem em casa. Achavam que isso era passageiro e que com o tempo os dois teriam mais responsabilidades, se tornariam companheiros. (FERRÉZ, 2013, p. 41). 
Por último e, por isso mesmo, com especial ênfase, está o olhar dilacerante lançado aos usuários de drogas e aos alcoólatras. Esses, sob a lente do narrador, encontram-se no degrau mais baixo de moralidade:

Como não estava passando nada que prestasse, foi ao quarto de sua mãe e a viu dormindo, seu pai estava no chão ao lado da cama, totalmente sujo. Ele tentou entender como um homem pode perder todo o caráter diante do álcool, mas decidiu não pensar nisso, não iria perder seu tempo novamente, pegou algumas revistas em quadrinhos, sentou à beira da cama e começou a entrar nas histórias de Garth Ennis, seu autor favorito. Leu algumas páginas, mas quando o pastor estava para matar os anjos rebeldes, ele dormiu. (FERRÉZ, 2013, p. 72).

Mixaria deu uma leda para cada um e começou a dichavar a maconha, cada um fumou o seu e ficou a pampa, curtindo a natureza e viajando cada um com seu sonho, não sabendo que o que estava subindo ali era fumaça, mas o que certamente estava descendo era a autoestima, que descia pelo esgoto. (FERRÉZ, 2013, p. 64).

É importante que notemos, no entanto, que apesar de criticar veemente determinados valores éticos e morais, a voz narrativa se mostra, ideologicamente, contrária ao protestantismo, situando as igrejas protestantes e respectivos pastores no mesmo lugar do patrão burguês - o de vilão. Valoriza, no entanto, a fé católica, sobre a qual são constantes várias referências no decorrer da obra. A religiosidade seletiva será, então, mais uma das marcas de uma voz que se insere nos liames dos discursos e que, deste lugar, encontra os elementos que serão mais capazes de atender às suas demandas ideológicas e ao jogo de relações de poder no ambiente social em que se insere.

Nesse intercâmbio de perspectivas em convergência e aproximação, a narrativa de Ferréz se constrói como uma obra dialógica, plural, que revela a falsa neutralidade dos discursos e a impossibilidade de separar o sujeito das vozes culturais e ideológicas que o perpassam continuamente. Ao delinear tais relações, coloca em xeque múltiplas identidades, inclusive a própria, realocando um imaginário cultural de antagonismos para um outro de bricolagem, antropofagia, que instaura uma realidade subjetiva marcada pela tentativa de construir um lugar no mundo. Tal construção é camaleônica, profusa, enfim, a marca de um novo tipo de favela, e de literatura - construída na pluralidade e no contraditório jogo de aceitação e de demarcação de sua própria face. 
Em síntese, verificamos que a voz narrativa de Capão pecado, embora se constitua sob o crivo da pedagogia e do didatismo, o faz de forma ambígua e, muitas vezes, contraditória. Não é, portanto, o que por senso comum, tendo em vista diversas manifestações literárias e artísticas, conhecemos por "moral da favela", que é ensinado pelo narrador. Tampouco, podemos afirmar que o narrador ensine o estilo de vida burguês ou pregue a inserção do sujeito aos modelos basilares do sistema capitalista. A despeito disso, a pedagogia de Capão pecado é situada no entre-lugar ideológico que existe nas frestas da oposição binária entre centro e margem, ou entre cidade e favela.

A voz narrativa da obra de Ferréz, portanto, ao considerar determinados valores pregoados pelo sistema e, ao mesmo tempo, apresentar elementos constituintes da moral da favela, sugere que pensemos para além das fronteiras físicas e políticas que dispõem o centro urbano e a favela em patamares totalmente distintos. Multifacetada, ambígua, a obra literária sugere um olhar para além dos binarismos, para o cerne das relações de poder, que, como vimos, são assimétricas e escorrem tanto pelos becos esquivos das favelas quanto pelos saguões luxuosos dos prédios das grandes cidades.

\title{
From the trap of power through the underlines of discourse: an ambiguous pedagogy of favela in Ferréz's Capão pecado
}

\begin{abstract}
In this work, I aim at discussing how the narrator of Capão pecado proposes a counterpoint to the moral code of marginality, establishing an ambiguous pedagogic voice that criticizes the "system" at same time that incorporate its rules of morality. For this task, I analyze the narrative voice of the work in question in articulation with Foucault's theory on power specially the concept of panopticism. With this study, I may verify that the moral value of traditional Brazilian bourgeoisie is not located in the top of a social pyramid, but transits through several structures. In this process, it breaks the frontiers of center and margin and establish itself as a norm even where it is questioned and subverted.
\end{abstract}

Keywords: Power. Brazilian Marginal Literature. Ferréz. Capão pecado. 


\section{Referências}

FERRÉZ. Amanhecer Esmeralda. Rio de Janeiro: Objetiva, 2005.

FERRÉZ. Capão pecado. São Paulo: Labortexto Editorial, 2000.

FERRÉZ. Capão pecado. São Paulo: Planeta, 2013.

FERRÉZ. Cronista de um tempo ruim. São Paulo: Selo Povo, 2009.

FERRÉZ. Deus foi almoçar. São Paulo: Planeta do Brasil, 2012.

FERRÉZ. Fortaleza da desilusão. São Paulo: [s.d.], 1997.

FERRÉZ. Manual Prático do ódio. Rio de Janeiro: Objetiva, 2003.

FERRÉZ. Ninguém é inocente em São Paulo. Rio de Janeiro: Objetiva, 2006.

FOUCAULT, Michel. Em defesa da sociedade: curso no Collège de France (1975-1976). Tradução de Maria Ermantina Galvão. São Paulo: Martins Fontes, 2002.

FOUCAULT, Michel. História da sexualidade I: a vontade de saber. Tradução de Maria Thereza da Costa Albuquerque e J.A. Guilhon Albuquerque. 7. ed. Rio de Janeiro: Graal, 1988.

FOUCAULT, Michel. Vigiar e punir: nascimento da prisão. 36. ed. Tradução de Raquel Ramalhete. Petrópolis: Vozes, 2009.

JESUS, Carolina Maria. Quarto de despejo: diário de uma favelada. Rio de Janeiro: Francisco Alves, 1966.

KRISTEVA, Julia. The power of horror: An essay on abjection. New York: Columbia University Press, 1986

LINS, Paulo. Cidade de Deus. São Paulo: Planeta, 2012.

LINS, Paulo. Paulo Lins e a estética da marginalidade: Entrevista. Disponível em http://augustasp.com/ruaaugusta/01/paulo-lins-e-a-estetica-da-marginalidade/. Acesso: 15/02/2014.

SANTIAGO, Silviano. Uma literatura nos trópicos: ensaios sobre dependência cultural. Rio de Janeiro: Rocco, 2000.

SANTOS, Maria Aparecida Costa. Ferréz: o rapper da literatura. In: Anais do primeiro colóquio internacional culturas jovens, Afro-Brasil América, São Paulo, 2012. 
VELLOSO, Luciana Mendes. Capão pecado: sem inspiração para cartão postal. Dissertação (Mestrado em Letras) - Faculdade de Letras, Universidade Federal de Minas Gerais. Belo Horizonte, 2007.

WOLFF, Janet. Feminine Sentences: essays on women and culture. Berkeley and Los Angeles: University of California Press, 1990.

Recebido em 27/04/ 2016

Aceito em 05/09/2016 